\title{
DEVELOPING SPEAKING SKILLS THROUGH FAIRY TALES IN ELEMENTARY SCHOOL
}

\author{
Manukyan A. M., PhD, Associate Professor at the Chair of Foreign Language Teaching \\ Methodology; \\ Durgaryan A. M., MA Student at the Foreign Language Faculty;
}

Armenia, Yerevan, Armenian State Pedagogical University after Khachatur Abovian

DOI: https://doi.org/10.31435/rsglobal_sr/31032019/6384

\section{ARTICLE INFO}

Received 16 January 2019

Accepted 16 March 2019

Published 31 March 2019

\section{KEYWORDS}

Speaking skills,

EFL teaching,

Fairy Tales,

Elementary school,

lesson activities.

\begin{abstract}
As the objective of EFL teaching is to help students to communicate fluently in the target language, teachers should provide authentic models of language use for every level and age. To hit the target we should focus not only on linguistic, but also on literary and cultural elements. Since fairy tales offer these elements, they are highly beneficial to use in EFL teaching programs, especially for young learners.

It should be taken into consideration that the selection of fairy tales should be done in reference to the course objective, the learners' age and the story content. Since every teaching situation is unique, the use of every single piece of fairy tale varies from class to class and from teacher to teacher. But, anyhow, using fairy tales in Elementary English courses as literary works tends to improve communicative competence and provide a springboard for the development of critical thinking and aesthetic appreciation. It is advantageous for many benefits, like cultural enrichment, language advancement, higher-order thinking, and many more. To accomplish the following purpose, there is a great significance given to the methodology and strategies to teaching English through Fairy Tales.
\end{abstract}

Citation: Manukyan A. M., Durgaryan A. M. (2019) Developing Speaking Skills Through Fairy Tales in Elementary School. Science Review. 3(20). doi: 10.31435/rsglobal_sr/31032019/6384

Copyright: (C) 2019 Manukyan A. M., Durgaryan A. M. This is an open-access article distributed under the terms of the Creative Commons Attribution License (CC BY). The use, distribution or reproduction in other forums is permitted, provided the original author(s) or licensor are credited and that the original publication in this journal is cited, in accordance with accepted academic practice. No use, distribution or reproduction is permitted which does not comply with these terms.

Introduction. When children start learning a foreign language they receive more input than they produce output. Moreover, as the pupils are young teachers must use something appealing to them. Hence, using fairy tales in the Elementary English curriculum is a good idea. Teaching English through Fairy Tales in Elementary School has a paramount value. Fairy Tales are an ideal and a unique introduction for teaching a foreign language as they present learning in a motivating and catchy context.

Children's starting consciousness of their first steps in another foreign context should have rudimentary basis during their first schooling period. Hence, the teaching process should embrace a measuring input and consequently it should be a complex of various materials and resources that should be involved in the world of a new foreign language. This specified inclination should be an outcome of a pure, coherent and worthwhile teaching. Children pursue to comprehend the awareness they are given which motivates them to broaden their knowledge frames in their learning period.

The aim of the study is to explore and investigate the principal specific features and properties of teaching English language through Fairy Tales at elementary school as a practical viewpoint.

The character and principal features of the scrutinizing study can be found in the works by Collie J, Slater S. [1987, p. 9-14]. The fairy tales spark children's curiosity, increase interest and create wonder and in addition to that they may elicit a powerful emotional response and personal involvement of students. According to Cameron stories offer the whole imaginary world, created by language that children can enter and enjoy, 
learning language as they read. Good stories provide a study of universal values and needs and capture students' interest and challenges them to explore new roads of meaning [2001, p.28-39]. They develop their literary competence- a combination of linguistic, socio-cultural, historical and semiotic awareness [Brumfit \& Carter 1986, p. 18]. Fairy tales are stories that illustrate our impulse toward a greater level of consciousness. They are fun, interesting, and appeal to the imagination of virtually all readers [Bagg, 1991].

Method. With the help of the methodology of developing speaking skills through Fairy Tales learners get opportunity to initiate their communicative skills and knowledge in another context and with different ways, which is more captivating and handy for the pupils of this age. Besides, it makes the lesson more tempting, congenial and prompting.

Children are always interested in Fairy Tales and it helps them not only to be more acknowledged but also learn English language effectively. Using Fairy Tales in teaching process is one of the best and most omnipresent structures for running through such skills as listening, reading, writing and speaking. Fairy Tales are an overriding and forceful source of knowledge for upgrading the four skills to all levels of language proficiency in the frameworks of teaching process. They are to be a mysterious and glorious world for the children of this age.

The methodology of developing speaking skills through Fairy Tales should be focused on children's foreign language skills and on the development of their communicative skills that will enable them to combine meanings and texts, words in real social contexts. This frame references comprises such activities as puzzles, crosswords, picture telling, letter scrambles, word bingos, lexical threads, etc.

\section{Activities to Develop Speaking Skills through Fairy Tales.}

In this paper we define each type of chosen activities, highlight the relative strengths and weaknesses of each, and discuss how teachers can choose among many options with two primary considerations: the importance of the effect and the crucial need to use multiple sources of information in making decisions. The chapter ends with suggestions to help teachers choose among the various options.

Discussions. After a content-based lesson, a discussion can be held for various reasons. The students may aim to arrive at a conclusion, share ideas about an event, or find solutions in their discussion groups. Before the discussion, it is essential that the purpose of the discussion activity is set by the teacher. In this way, the discussion points are relevant to this purpose, so that students do not spend their time chatting with each other about irrelevant things. For example, students can become involved in agree/disagree discussions. In this type of discussions, the teacher can form groups of students, preferably 4 or 5 in each group, and provide controversial sentences. Then each group works on their topic for a given time period, and presents their opinions to the class. It is essential that the speaking should be equally divided among group members. At the end, the class decides on the winning group who defended the idea in the best way. This activity fosters critical thinking and quick decision making, and students learn how to express and justify themselves in polite ways while disagreeing with the others. For efficient group discussions, it is always better not to form large groups, because quiet students may avoid contributing in large groups. The group members can be either assigned by the teacher or the students may determine it by themselves, but groups should be rearranged in every discussion activity so that students can work with various people and learn to be open to different ideas. Lastly, in class or group discussions, whatever the aim is, the students should always be encouraged to ask questions, paraphrase ideas, express support, check for clarification, and so on.

Brainstorming. On a given topic the pupils express different ideas and thoughts in a limited time. Depending on the context, either the individual or group brainstorming is effective and learners generate ideas quickly and freely. The good feature of brainstorming is that the pupils aren't criticized for their ideas so pupils have an opportunity to share their new ideas.

Picture Narrating. This activity is based on several sequential pictures. Pupils are asked to tell the story taking place in the sequential pictures by paying attention to the criteria provided by the teacher as a rubric. Rubrics can include the vocabulary or structures they need to use while narrating.

Picture Describing. Another way to make use of pictures in a speaking activity is to give students just one picture and having them describe what it is in the picture. For this activity students can form groups and each group is given a different picture. Students discuss the picture with their groups, then a spokesperson for each group describes the picture to the whole class. This activity fosters the creativity and imagination of the learners as well as their public speaking skills. 
Find the Differences. For this activity students can work in pairs and each couple is given two different pictures, for example, picture of boys playing football and another picture of girls playing tennis. Students in pairs discuss the similarities and/or differences in the pictures.

Story Completion. This is a very enjoyable, whole-class, free-speaking activity for which students sit in a circle. For this activity, a teacher starts to tell a story, but after a few sentences he or she stops narrating. Then, each student starts to narrate from the point where the previous one stopped. Each student is supposed to add from four to ten sentences. Students can add new characters, events, descriptions and so on.

Storytelling. Students can briefly summarize a tale or story they heard from somebody beforehand, or they may create their own stories to tell their classmates. Story telling fosters creative thinking. It also helps students express ideas in the format of beginning, development, and ending, including the characters and setting a story has to have. Students also can tell riddles or jokes. For instance, at the very beginning of each class session, the teacher may call a few students to tell short riddles or jokes as an opening. In this way, not only will the teacher address students' speaking ability, but also get the attention of the class.

Stimulation. Simulations are very similar to role-plays but what makes simulations different than role plays is that they are more elaborate. In simulations, students can bring items to the class to create a realistic environment. For instance, if a student is acting as a singer, she brings a microphone to sing and so on. Role plays and simulations have many advantages. First, since they are entertaining, they motivate the students. Second, as Harmer (1984) suggests, they increase the self-confidence of hesitant students, because in role play and simulation activities, they will have a different role and do not have to speak for themselves, which means they do not have to take the same responsibility.

Role play. One other way of getting students to speak is role-playing. Students pretend they are in various social contexts and have a variety of social roles. In role-play activities, the teacher gives information to the learners such as who they are and what they think or feel. Thus, the teacher can tell the student that "You are David, you go to the doctor and tell him what happened last night, and..."

Results of the investigation. In order to give the answer to the research: Alternative Developing Speaking Skills through Fairy Tales in Elementary school, two types of data (quantitative and qualitative) were collected in this study. In terms of qualitative section, we opted for a phenomenological approach to investigate pupils' experiences and their perceptions of speaking skills in the classroom. We have chosen this approach, because we were interested in developing speaking skills during English lessons through fairy Tales.

Furthermore, as we divided our survey into two parts: activities for developing speaking skills with pupils and questionnaires for teachers. So we realized our survey at two schools in the Republic of Armenia at the same time: school \#11 after William Saroyan and school\# 5 in Hrazdan region from April to May 2018 as this theme is taught in that period of time by state educational curriculum. We have chosen two schools in order to realize two types of lesson plans. The first one was formed according to state school program of teaching English at school. The second plan was formed and realized by ourselves according to our research aim and hypothesis. Our aim was to manifest the differences and the effectiveness of our activities in speaking skills.

To conduct the research we chose the fairy tale "Cinderella", as it is popular worldwide. We illustrate some examples of activities and games which proved to be motivating and practical techniques used in Elementary School for Teaching English. The aim of the research was to make the learning process cheerful, motivating and rewarding.

The aim of the activities chosen by us are the following:

- To develop reading comprehension, to increase pupils' confidence in reading,

- To check the pronunciation of the words, and listening comprehension,

- To expand the learners' vocabulary (both spoken and written form),

- To develop the students' intellectual skills while they search and discover,

- To build up the learners' self-assurance in performance before the class and to help them control their timidity,

- To boost their physical development,

- To developing students' critical thinking and creativity. 
Activity 1.

Put the pictures in the right order.

Aim: Encourage learners to memorize the plot of the Fairy Tale and try to retell it with the help of the pictures.
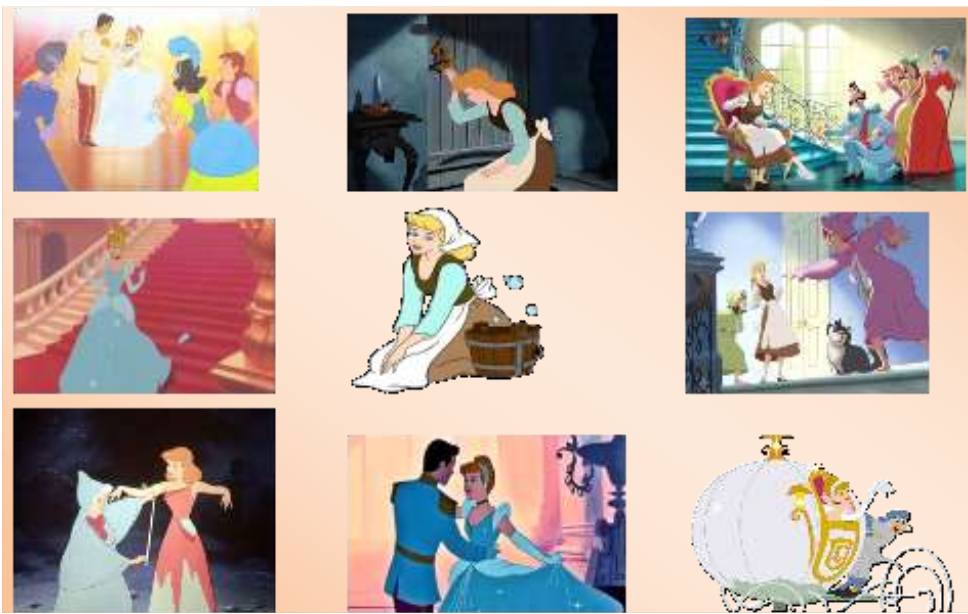

देर्द

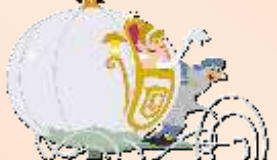

\section{Activity 2.}

Draw a picture while you listen and tell your story.

Aim: Developing listening skills, as the learners listen to teacher's instructions and try to draw.

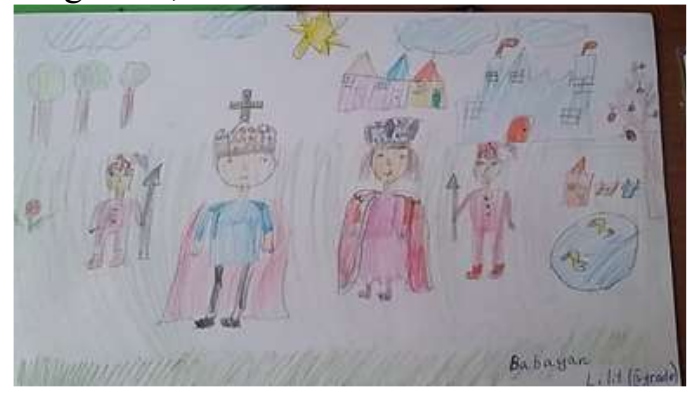

Activity 3.

Match the opposite adjectives.

Aim: To enhance vocabulary with adjectives and their antonyms.

\section{Activity 4}

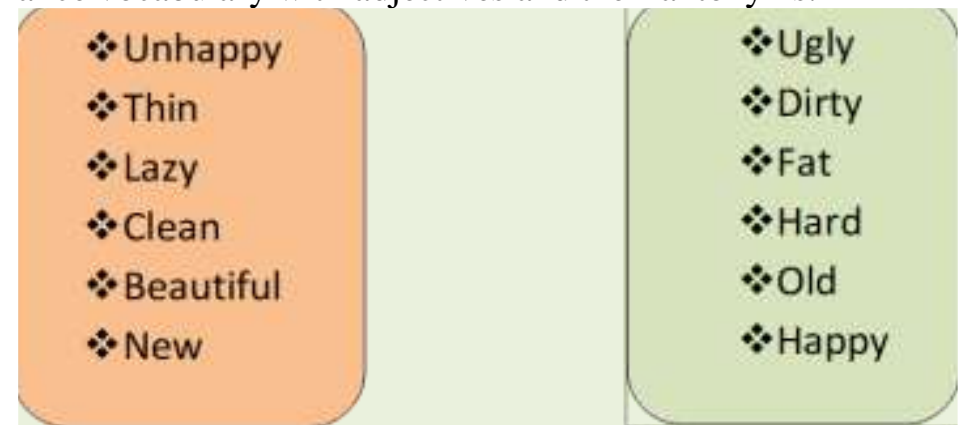

Put the statements in the correct order

Aim: To develop retelling and speaking skills

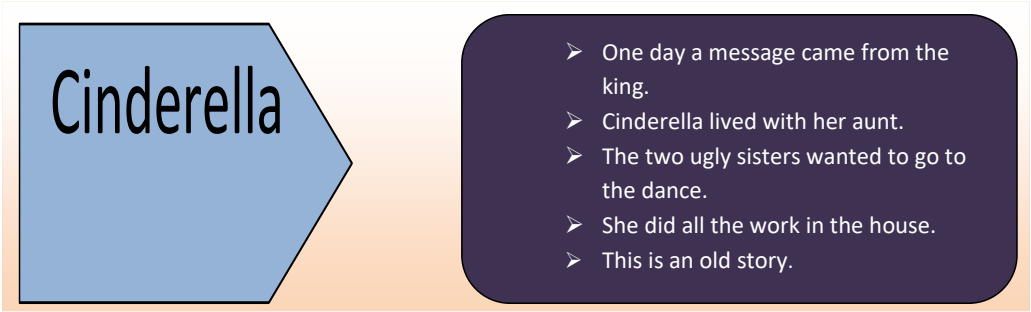


Activity 5

Find the words mentioned in the text

Aim: To advance listening and speaking skills through listening

\begin{tabular}{|c|c|c|c|}
\hline pumpkin & family & friend & voice \\
\hline Living-room & town & stick & table \\
\hline secretary & midnight & interesting & coach \\
\hline dance & pudding & lady & shoe \\
\hline
\end{tabular}

\section{Activity 6}

Match the words with the pictures.

Aim: Activate the new vocabulary.
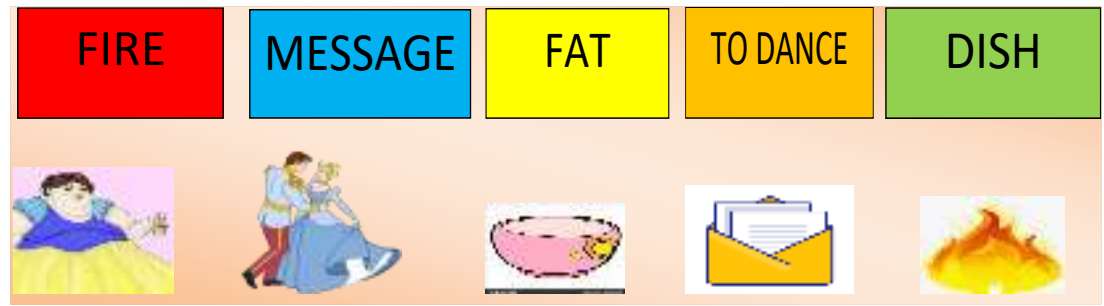

Conclusions. The activities designed by us proved to be really productive: we could use effective strategies and techniques to further the pupils' proficiency and skills of English.

Thereafter we assembled a range of experimental lessons, did surveys with questionnaires for teachers and successfully proved that the set of activities chosen by us enriches and reinforces the students' speaking skills as well as stimulates the usage of English.

\section{REFERENCES}

1. Bagg, M. B. (1991). Folk Literature in the Foreign Language Classroom. Retrived from http://eric.ed.gov/ERICWebPortal/contentdelivery/servlet/ERICServlet?accno=ED343432, accessed April 18,2012

2. Brumfit, C. and Carter. R.1986. Literature and Language Teaching. Oxford: Oxford U. p. 290

3. Branett, M. A. (1988). Teaching Reading in a Foreign Language. ERIC Digest. Retrieved from http://www.ericdigests.org/pre-9211/reading.htm, accessed April 14, 2012

4. Cameron, L. 1994. "Organizing the World: Children's Concepts and Categories, and Implications for the Teaching of English”. ELT Journal Volume 48 (1): 28-39.

5. Collie, J., Slater, S. (1987). Literature in the Language Classroom. A resource book of ideas and activities. Great Britain: Cambridge University Press.

6. Hunt, P. 1994. An Introduction to Children's Literature. Oxford, New York: Oxford University Press.

7. Lazar, G. 1993. Literature and Language Teaching. Great Britain: Cambridge University Press.https://www.slideshare.net/XaavJata/209402426gillianlazarliteratureandlanguageteachingaguideforte achersandtrainers 19931

8. Ur, P. 1996. A Course in Language Teaching. Great Britain: Cambridge University Press. 